Jurnal Informatika dan Rekayasa Perangkat Lunak (JATIKA)
Vol. 1, No. 2, December 2020, 215-225
ISSN 2723-3367
available online at:http://iim.teknokrat.ac.id/index.php/informatika

\title{
APLIKASI PEMESANAN CATERING DI KOTA BANDAR LAMPUNG BERBASIS WEB
}

\author{
Naufal Ravizan Pradana \\ S1 Informatika, Universitas Teknokrat Indonesia \\ naufalravizan@gmail.com
}

Received: (Desember 2020) Accepted: (Desember 2020) Published: (Desember 2020)

\begin{abstract}
Consumers are increasingly being trained that the use of the Internet is becoming a potential market for many companies. On the other hand, for local businesses, this is a way to improve service to customers and expand reach to add new customers. For the catering industry. the availability of information and communication technology can be used for these two purposes, including the catering industry which can provide services and products to end users and intermediate sellers. In particular, this article will discuss how to develop online information system tools for catering business management. In this study the authors used a prototype system development method. Website development is done using the PHP programming language and HTML with the MYSQL database. Then ISO 25010 testing was carried out based on three characteristics, namely Functional Suitability, Performance Efficiency and Usability. The results of this study will produce a website that can implement promotional and marketing applications for catering packages, promotion and delivery of catering package information and package prices in detail to consumers and equipped with catering package sales transactions.
\end{abstract}

Keywords: E-Commerce, CodeIgniter, Catering, Paket, website.

\begin{abstract}
Abstrak
Konsumen semakin terlatih dengan penggunaan Internet menjadi pasar potensial bagi banyak perusahaan. Di sisi lain, bagi pebisnis lokal, ini merupakan cara meningkatkan pelayanan kepada pelanggan dan memperluas jangkauan untuk menambah pelanggan baru. Untuk industri catering. ketersediaan teknologi informasi dan komunikasi dapat digunakan untuk dua tujuan tersebut, termasuk industri catering yang dapat memberikan layanan dan produk kepada pengguna akhir dan penjual perantara. Secara khusus artikel kali ini akan membahas bagaimana mengembangkan perangkat sistem informasi online untuk manajemen bisnis catering. Metode pengumpulan data yang digunakan dalam penelitian ini (Cetering Plase Research), yaitu penelitian dilakukan dengan cara mendatangi tempat secara langsung dan dengan pengumpulan data sekunder.. Pembangunan website dilakukan dengan menggunakan bahasa pemrograman PHP dan HTML dengan database MySQL. Kemudian dilakukan pengujian ISO 25010 berdasarkan tiga karakteristik yaitu Functional Suitability, Performance Efficiency dan Usability. Hasil dari penelitian ini akan menghasilkan sebuah website yang dapat mengimplementasikan aplikasi promosi dan pemasaran paket catering, promosi serta penyampaian informasi paket catering dan harga paket secara detail kepada konsumen serta dilengkapi dengan transaksi penjualan paket catering.
\end{abstract}

Kata Kunci: E-Commerce, Website, CodeIgniter, Catering, Paket

To cite this article:

Naufal Ravizan. (2020). APLIKASI PEMESANAN CATERING DI KOTA BANDAR LAMPUNG BERBASIS WEB. Jurnal Informatika dan Rekayasa Perangkat Lunak, Vol(1) No(2), 215-225. 


\section{PENDAHULUAN}

Perkembangan industri catering di Bandar Lampung didukung oleh perkembangan industri catering. Perkembangan industri catering yang semakin banyak dibantu oleh teknologi di bidang informasi dan komunikasi (khususnya internet). Internet memegang peranan penting dalam memudahkan konsumen dalam memperoleh informasi catering. Selain itu, internet juga dapat memberikan peluang kepada pengusaha catering untuk menjual produknya.

Jumlah penduduk lokal dan orang asing yang makan di Bandar Lampung semakin meningkat, salah satunya adalah permintaan masyarakat yang besar terhadap industri catering, karena masyarakat meyakini pengembalian modal dari industri catering relatif tinggi. Dapat memenuhi kebutuhan utama masyarakat. Hal ini terlihat dari semakin banyaknya perusahaan catering yang sukses dan berkembang.

Perkembangan teknologi juga diiringi dengan permintaan yang tinggi (Suryono, Nurhuda and Ridwan, 2019). Keberadaan internet merupakan salah satu pendukung dalam kehidupan sehari-hari masyarakat, konsumen kini semakin mudah memesan paket makanan catering yang diinginkan, dan dapat mengetahui berbagai informasi lainnya, seperti menu paket makanan catering dan harga yang disediakan oleh pemilik catering.

Konsumen semakin terlatih penggunaan Internet menjadi pasar potensial bagi banyak perusahaan bagi pebisnis lokal, ini merupakan cara untuk meningkatkan pelayanan kepada pelanggannya dan memperluas jangkauannya untuk menambah pelanggan baru. Untuk industri catering. ketersediaan teknologi informasi dan komunikasi dapat digunakan untuk dua tujuan tersebut, termasuk industri catering yang dapat memberikan layanan dan produk kepada pengguna akhir dan penjual perantara. Secara khusus artikel kali ini akan membahas bagaimana mengembangkan perangkat sistem informasi online untuk manajemen bisnis catering.

\section{TELAAH PUSTAKA \\ XAMPP}

XAMPP merupakan paket $P H P$ yang dikembangkan oleh komunitas Open Source. XAMPP tidak dibingungkan dengan penginstalan program karena semua kebutuhan aplikasi tersedia oleh XAMPP sebagai server (localhost) terdiri atas program Apache HTTP Server, MySQL database dan penerjemah ditulis dalam bahasa pemrograman PHP dan Perl. Program ini tersedia dalam GNU (General Public License) mudah digunakan melayani tampilan halaman web yang dinamis.

1. Apache

Menurut (Bunafit, 2014), "Web server untuk menjalankan aplikasi web berbasis PHP".

2. phpMyadmin

Menurut (Solichin, 2016), "Sebuah software yang berbentuk seperti halaman situs yang terdapat pada web server".

\section{CodeIgniter}

CodeIgniter adalah sebuah framework berbasis PHP yang kuat dengan footprint yang sangat kecil, dibangun untuk pengembang yang membutuhkan toolkit sederhana dan elegan untuk membuat aplikasi web dengan fitur lengkap. Lantas Framework atau dalam bahasa indonesia dapat diartikan sebagai "kerangka kerja" merupakan sebuah tool yang bekerja pada sebagai lingkup kerjanya, dia harus mematuhi segala ketentuan dari framework tersebut. Lebih lanjut ia dapat membangun berbagai fungsi yang rumit dan kompleks dengan menggunakan fungsi - fungsi yang telah disediakan oleh framework tersebut. Jadi dia tidak perlu lagi menulis ulang semua coding, Ia cukup mempelajari cara menggunakan kerangka (frame) yang telah tersedia dari framework tersebut (Wardana, 2010).

\section{Model}

Bagian yang bertanggung jawab terhadap operasi database, baik itu create, read, update atau delete. Ia berupa fungsifungsi operasional database yang dapat dipanggilkan oleh controller.

\section{View}

Bagian yang menangani tampilan. bagian inilah yang bertugas untuk mempresentasikan data kepada user. Ia berbentuk struktur $H T M L$ yang berisikan variabel data yang dikirimkan oleh controller.

\section{Controller}

Bagian yang mengatur hubungan antara Model dan View. Ia adalah otak dari kinerja aplikasi. Ia terdiri dari fungsifungsi yang bersifat operasional dan logikal. Saat ada request yang masuk, ia akan menangani dan memprosesnya untuk kemudian ditampilkan dalam View 


\section{METODE PENELITIAN}

\section{Kerangka Penelitian}

Kerangka penelitian digunakan untuk dapat membantu menyelesaikan permasalahan sehingga hasil yang didapat lebih sistematis dan terarah (Ahdan and Sari, 2020). Metode pengumpulan data yang digunakan dalam penelitian ini dilakukan dengan penelitian tempat catering (Cetering Plase Research), yaitu penelitian dilakukan dengan cara mendatangi tempat secara langsung dan dengan pengumpulan data sekunder.

\section{Teknik Pengumpulan Data}

Tahapan ini memperoleh data sebagai bahan penelitian dengan menggunakan beberapa metode dalam melakukan penelitian yaitu sebagai berikut:

1. Pengamatan : Metode ini dilakukan dengan cara pengumpulan data melalui proses pengamatan secara langsung kepada tempat catering.

2. Wawancara : Metode ini dilakukan dengan cara mengajukan pertanyaan secara langsung dengan pimpinan tempat catering.

\section{HASIL DAN PEMBAHASAN}

\section{A. Usecase Diagram}

Usecase Diagram menggambarkan sistem dari sudut pandang pengguna sistem tersebut (user), sehingga pembuatan Usecase diagram ini lebih dititik beratkan pada fungsionalitas yang ada pada sistem, bukan berdasarkan alur atau urutan kejadian (Irvansyah, Muhaqiqin and Setiawansyah, 2020). Usecase diagram aplikasi pemesanan paket catering dapat dilihat pada Gambar 3.3.

Tabel 1. Analisis Aktor

\begin{tabular}{|l|c|}
\hline \multicolumn{1}{|c|}{ Aktor } & Deskripsi \\
\hline Admin & $\begin{array}{c}\text { Orang yang bertugas mengelola dan menginputkan data informasi ke } \\
\text { sistem . }\end{array}$ \\
\hline Masyarakat & Orang yang mencari data tempat catering beserta informasinya. \\
\hline
\end{tabular}

Tabel 2. Analisis Use case

\begin{tabular}{|c|c|l|}
\hline Nama $\boldsymbol{U S E}$ CASE & Aktor & $\begin{array}{l}\text { Otentifikasi sistem digunakan } \\
\text { oleh orang yang valid }\end{array}$ \\
\hline Mengelola Catering & Admin & $\begin{array}{l}\text { Admin dapat merubah } \\
\text { dan menginputkan data menu } \\
\text { paket paket makanan } \\
\text { catering, harga. }\end{array}$ \\
\hline Mengelola Admin & Admin & $\begin{array}{l}\text { Admin dapat menghapus, } \\
\text { melihat dan menambah paket } \\
\text { paket makanan catering, } \\
\text { harga. }\end{array}$ \\
\hline Melihat Paket Catering & Masyarakat & $\begin{array}{l}\text { Masyarakat dapat melihat dan } \\
\text { memesan paket paket } \\
\text { makanan catering beserta } \\
\text { informasinya dan harganya. }\end{array}$ \\
\hline
\end{tabular}




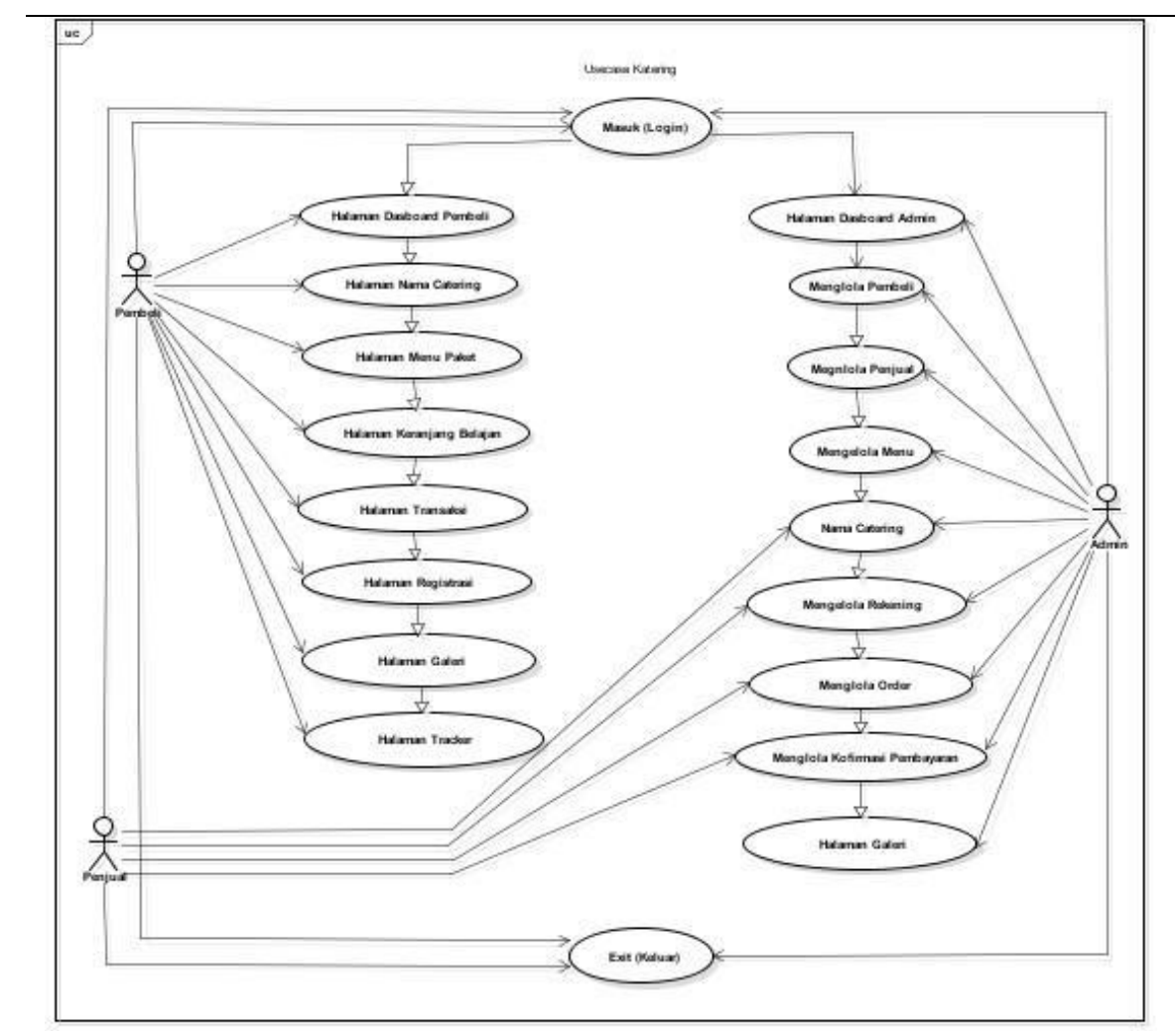

Gambar 1. Usecase Catering

\section{B. Activity Diagram}

Activity diagram digunakan untuk menggambarkan aliran kerja (workflow)dari kejadian Usecase system (Pasha and Suryani, 2017). Gambar ini adalah diagram aktivitas yang berhubungan dengan aliran kejadian untuk Usecase sistem aplikasi pemetaan lokasi catering. Activity diagram pada sistem ini terbagi atas 2 bagin yaitu activity diagram pengguna dan diagram pemilik.

\section{Activity Diagram Admin}

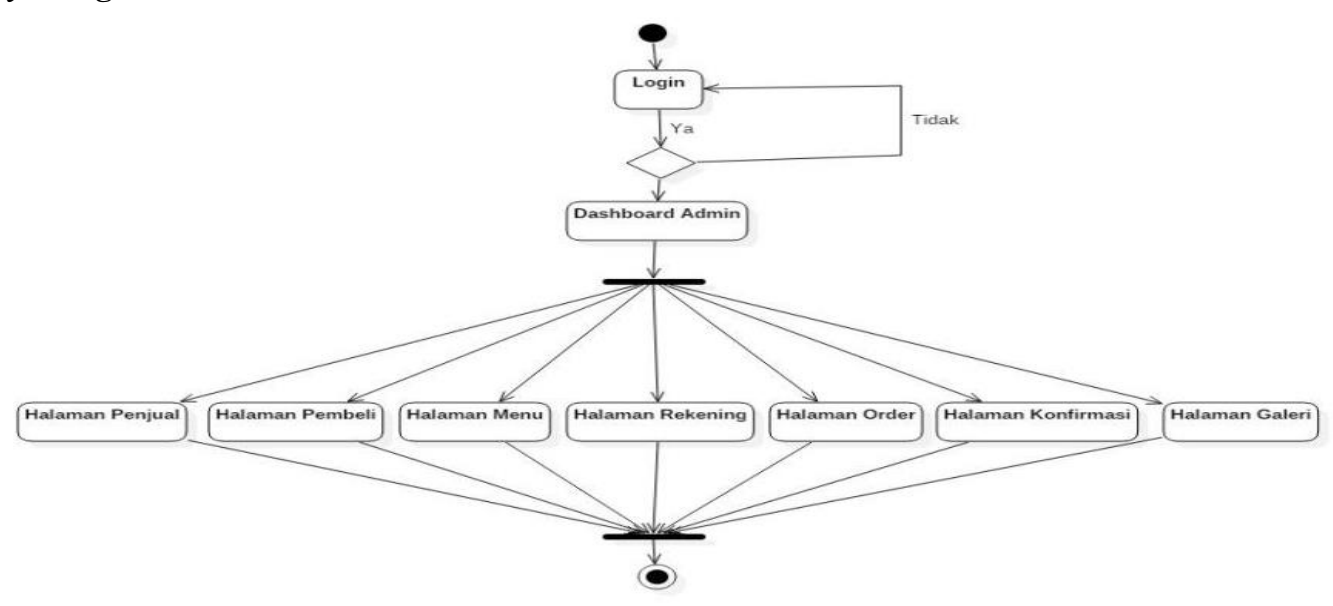

Gambar 2. Activity Diagram Admin 


\section{Activity Diagram Penjual}

Berikut ini adalah gambar Activity Diagram Booking dari aplikasi pemetaan catering.

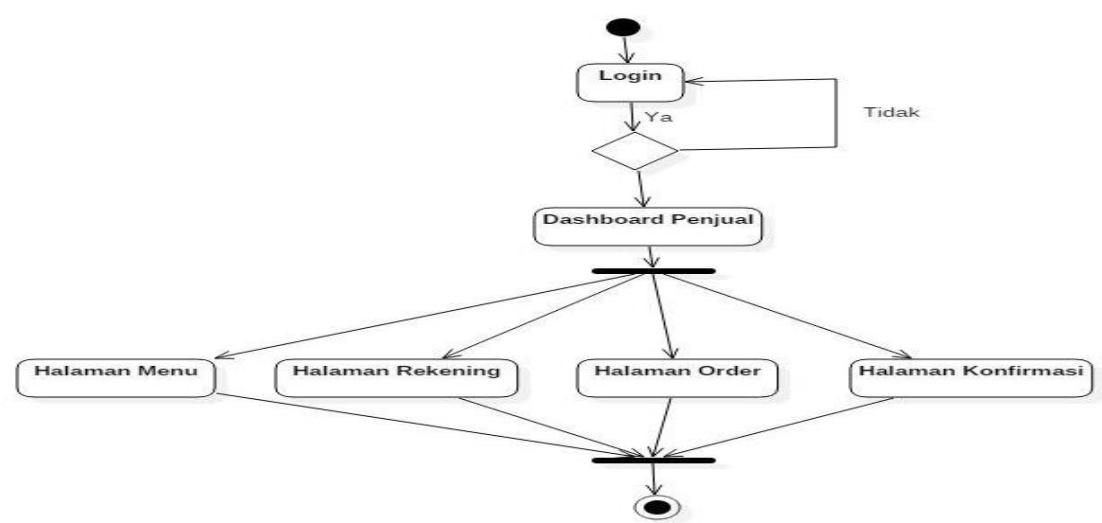

Gambar 3. Activity Diagram Penjual Catering.

\section{Activity Diagram Pembeli}

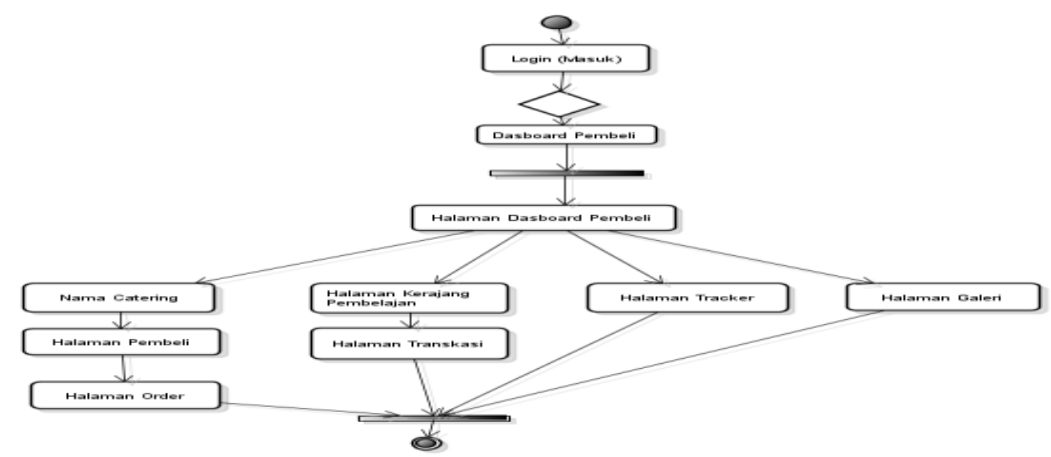

Gambar 4. Activity Diagram Pembeli

\section{Activity Diagram Class}

Berikut ini adalah gambar class diagram Class dari aplikasi catering

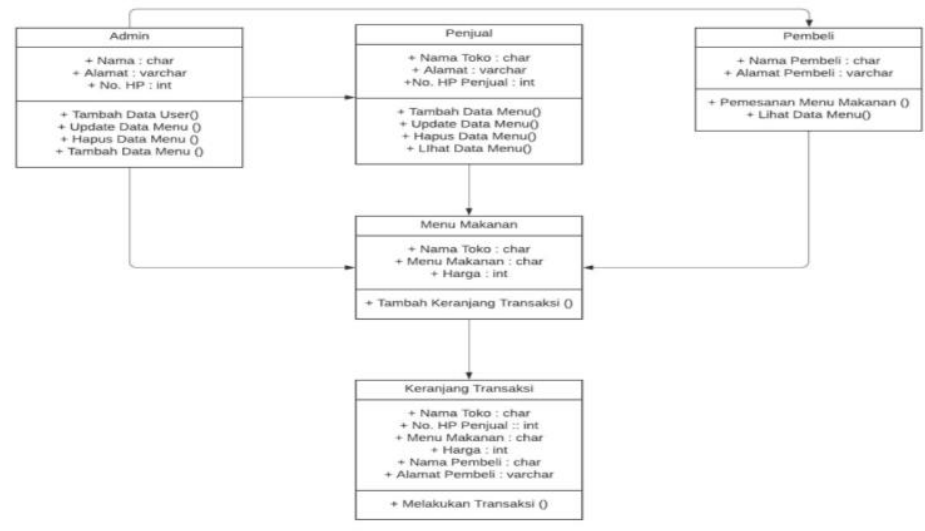

Gambar 5. Diagram Class

219 


\section{IMPLEMENTASI}

Merupakan tahap translasi yang telah dirancang ke dalam kode program, implementasi yang dilakukan meliputi implementasi antar muka / user interface (Mulyanto, Nurhuda and Khoirurosid, 2017). Sesuai dengan rancangan yang sudah dibuat, maka hasil implementasi dari rancangan antar muka adalah sebagai berikut:

\section{Halaman Login (Admin)}

Halaman Login admin adalah halaman yang hanya tampil pada pengguna admin. Pada halaman ini admin melakukan Login untuk masuk ke dashboard admin. Hasil implementasi Login admin dapat dilihat pada Gambar berikut:

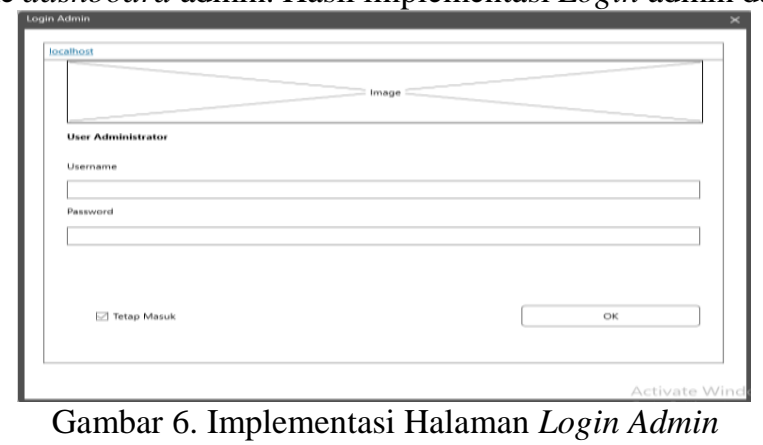

\section{Implementasi Halaman Menu Utama (Admin)}

Halaman Menu utama admin adalah halaman yang hanya tampil pada pengguna admin. Pada halaman ini akan menampilkan penjualan bulan sebelumnya, penjualan bulan ini, total porsi, total pelanggan, statistik penjualan, order terbaru, statistik pelanggan dan pelanggan terbaru. Hasil implementasi menu utama admin dapat dilihat pada Gambar berikut:

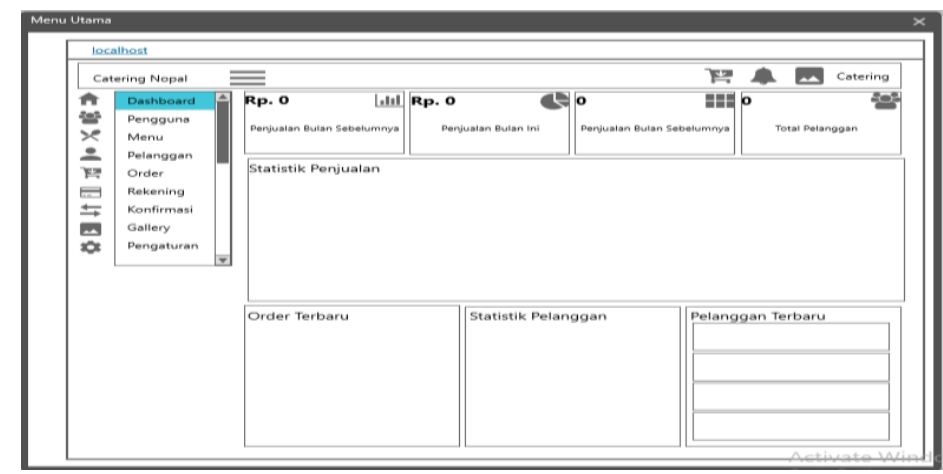

Gambar 7. Implementasi Halaman Menu Utama Admin

\section{Implementasi Halaman Data pelanggan (Admin)}

Halaman data pelanggan adalah halaman yang hanya tampil pada pengguna admin. Pada halaman ini admin dapat melihat dan menghapus data pelanggan. Hasil implementasi Data pelanggan dapat dilihat pada Gambar berikut: 


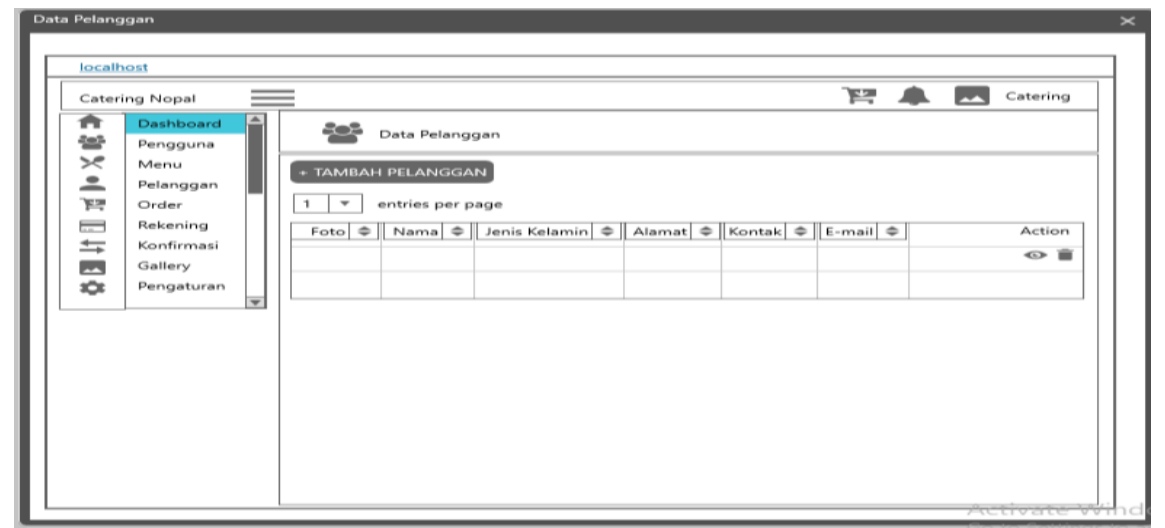

Gambar 8. Implementasi Tampilan Data pelanggan

\section{Implementasi Halaman Data Menu (Admin)}

Pada halaman ini admin dapat menambah, melihat, mengubah dan menghapus data menu paket makanan catering. Hasil implementasi data menudapat dilihat pada Gambar berikut:

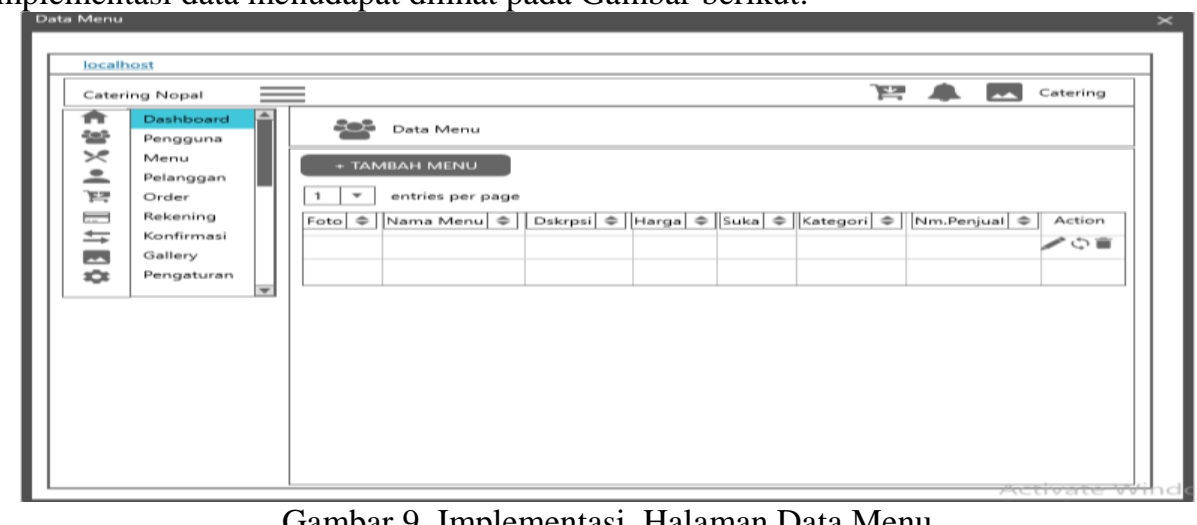

Gambar 9. Implementasi Halaman Data Menu

\section{Implementasi Halaman Data Order (Admin)}

Halaman data order adalah halaman pemesanan pelanggan. Pada halaman ini admin dapat melihat, mengubah dan menghapus data order. Hasil implementasi data order dapat dilihat pada Gambar berikut:

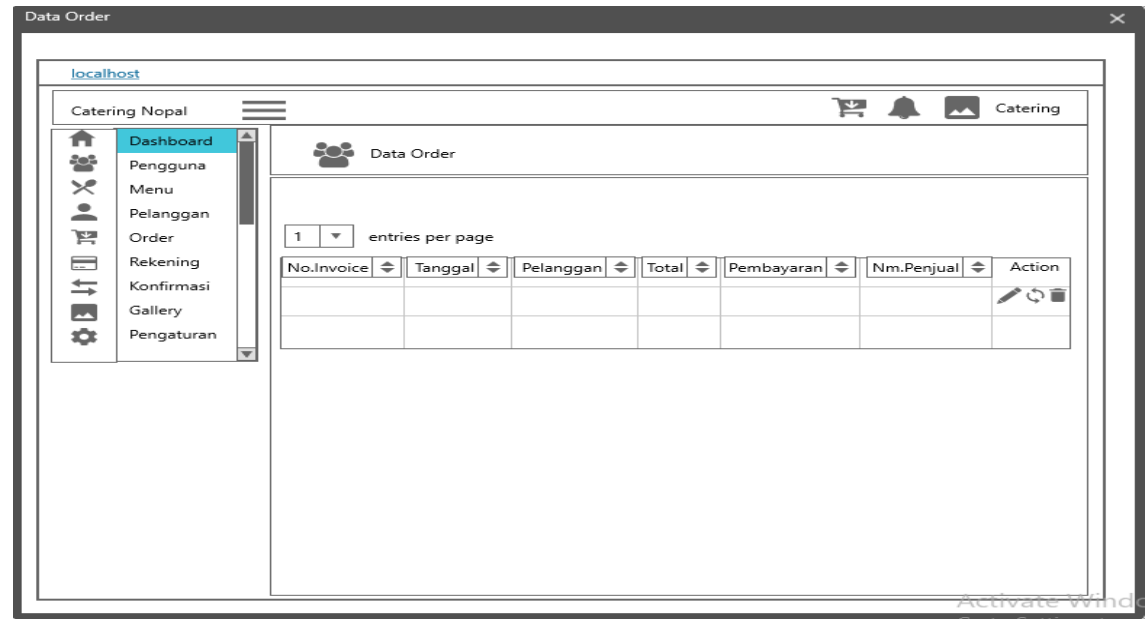

Gambar 10. Implementasi Halaman Data Order 


\section{Implementasi Halaman Data Galeri (Admin)}

Halaman data galeri adalah halaman data galeri paket makanan catering. Pada halaman ini admin dapat menambah, mengubah, melihat dan menghapus data galeri. Hasil implementasi data galeri dapat dilihat pada Gambar 3.15 berikut:

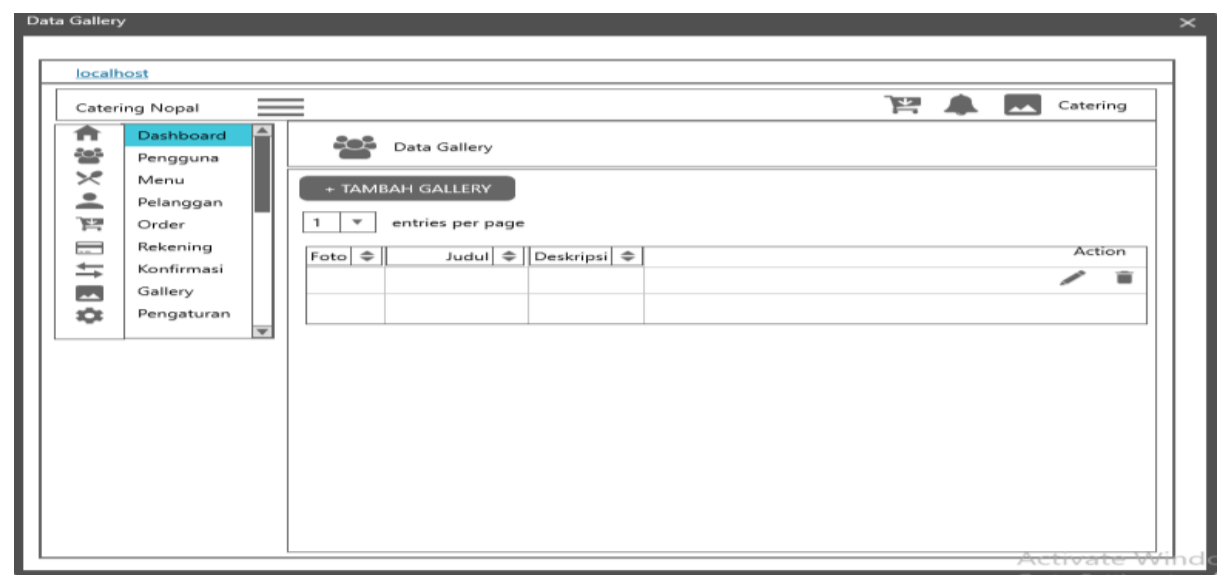

Gambar 11. Implementasi Halaman Data Galeri

\section{Implementasi Halaman Keranjang Belanja (Pembeli)}

Halaman keranjang belanja adalah daftar yang telah pembeli pilih untuk dilakukan transaksi. Pada halaman ini pembeli dapat melihat dan menghapus daftar belanja. Hasil implementasi keranjang belanja pembeli dapat dilihat pada Gambar berikut:

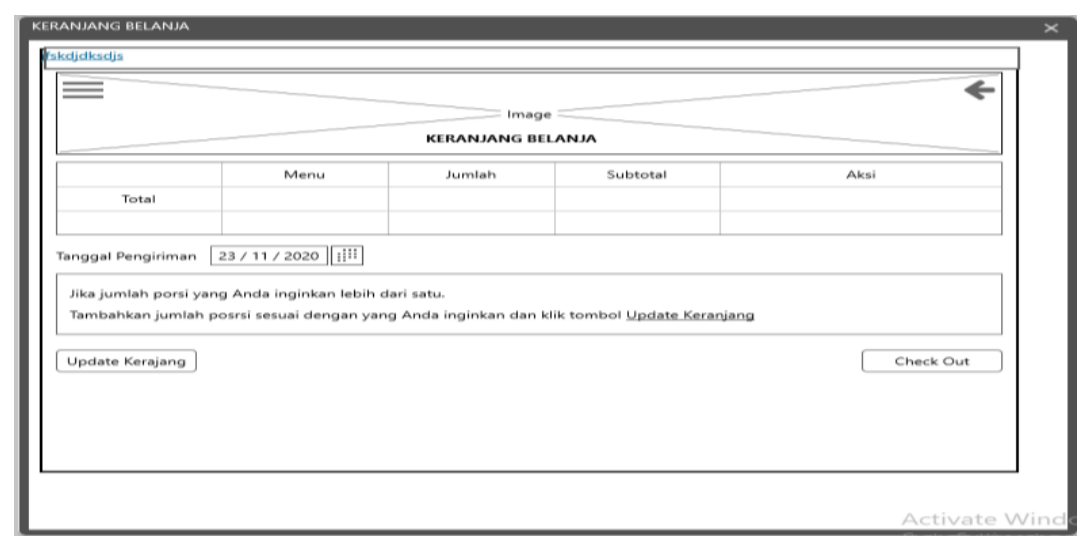

Gambar 12. Implementasi Halaman Keranjang Belanja Pembeli

\section{PENGUJIAN SISTEM}

\section{Pengujian Aspek Usability}

Pada aspek ini, metode yang digunakan yaitu dengan menggunakan kuesioner yang diberikan kepada pelanggan, pengguna dan admin dengan jumlah 5 rangkap kuisioner dan dengan cara mencoba aplikasi terlebih dahulu sebelum mengisi kuisioner (Megawaty et al., 2020), (Kurniawan, Setiawansyah and Nuralia, 2020).

Pengujian menggunakan 5 kategori jawaban dengan bobot yang berbeda untuk setiap jawabannya yaitu :

Sangat Setuju (5), Setuju (4), Ragu ragu (3), Tidak Setuju (2), Sangat Tidak Setuju (1). 
Tabel 2. Hasil Pengujian Usability

\begin{tabular}{|c|c|c|c|c|c|c|c|}
\hline \multirow{2}{*}{ No } & \multirow[t]{2}{*}{ Karakteristik } & SS & ST & RG & TS & STS & \multirow{2}{*}{ Skor } \\
\hline & & 5 & 4 & 3 & 2 & 1 & \\
\hline \multicolumn{8}{|c|}{ Performance } \\
\hline 1 & Apakah tampilan aplikasi mudah dikenali ? & 5 & 0 & 0 & 0 & 0 & 25 \\
\hline 2 & $\begin{array}{l}\text { Apakah menu dan tampilan halaman aplikasi } \\
\text { mudah diingat? }\end{array}$ & 3 & 2 & 0 & 0 & 0 & 23 \\
\hline 3 & Apakah mudah mengakses informasi detail ? & 0 & 3 & 3 & 0 & 0 & 21 \\
\hline 4 & Apakah aplikasi mudah dioperasikan ? & 4 & 1 & 0 & 0 & 0 & 24 \\
\hline 5 & $\begin{array}{l}\text { Apakah menu transaksi pembelian tersedia } \\
\text { mudah diakses? }\end{array}$ & 1 & 4 & 0 & 0 & 0 & 21 \\
\hline 6 & $\begin{array}{l}\text { Apakah tampilan warna pada aplikasi enak } \\
\text { dilihat \& tidak membosankan? }\end{array}$ & 3 & 2 & 0 & 0 & 0 & 23 \\
\hline 7 & Aplikasi catering mudah digunakan? & 1 & 1 & 3 & 0 & 0 & 18 \\
\hline 8 & $\begin{array}{l}\text { Fiture yang terdapat pada aplikasi catering } \\
\text { mudah dimengerti? }\end{array}$ & 4 & 1 & 0 & 0 & 0 & 24 \\
\hline 9 & $\begin{array}{l}\text { Tampilan warna pada aplikasi catering } \\
\text { bagus dilihat dan tidak membosankan? }\end{array}$ & 2 & 3 & 0 & 0 & 0 & 22 \\
\hline 10 & $\begin{array}{l}\text { Aplikasi catering mempermudah dalam } \\
\text { mencari informasi? }\end{array}$ & 2 & 3 & 0 & 0 & 0 & 22 \\
\hline 11 & Aplikasi catering bersifat user frenly? & 3 & 2 & 0 & 0 & 0 & 23 \\
\hline 12 & $\begin{array}{l}\text { Pengoprasian aplikasi catering lancer dan } \\
\text { setabil pada browser? }\end{array}$ & 2 & 0 & 3 & 0 & 0 & 19 \\
\hline 13 & Aplikasi menyajikan informasi yang akurat? & 3 & 2 & 0 & 0 & 0 & 23 \\
\hline 14 & $\begin{array}{lcc}\text { Aplikasi } & \text { sangat membantu pencarian } \\
\text { informasi } & \text { sesuai dengan kebutuhan? }\end{array}$ & 2 & 2 & 1 & 0 & 0 & 21 \\
\hline 15 & $\begin{array}{l}\text { Aplikasi menghasilkan informasi cukup } \\
\text { lengkap dan up-to date? }\end{array}$ & 3 & 0 & 2 & 0 & 0 & 21 \\
\hline 16 & $\begin{array}{l}\text { Anda puas dengan aplikasi catering yang } \\
\text { digunakan? }\end{array}$ & 1 & 4 & 0 & 0 & 0 & 21 \\
\hline 17 & $\begin{array}{l}\text { Apakah informsi catering sudah sesuai } \\
\text { dengan kebutuhan? }\end{array}$ & 3 & 1 & 1 & 0 & 0 & 22 \\
\hline 18 & $\begin{array}{l}\text { Anda puas dengan tampilan dan fiture yang } \\
\text { disajikan oleh aplikasi catering? }\end{array}$ & 4 & 1 & 0 & 0 & 0 & 24 \\
\hline \multicolumn{2}{|c|}{ Total Skor } & & & & & & 834 \\
\hline
\end{tabular}

Berdasarkan hasil kuisioner pengujian usability yang telah dilakukan dapat di hitung menggunakan perhitungan skala likert menurut (Sugiyono, 2018). Dikethahui bahwa pada kuisioner tersebut memiliki 5 pembobotan nilai yaitu yaitu Sangat Setuju (SS) bernilai 5, Setuju (ST) bernilai 4, Ragu-ragu (RG) bernilai 3, Tidak Setuju (TS) bernilai 2, Sangat Tidak Setuju (STS) bernilai 1. maka skor yang diperoleh akan dibagi nilai tertinggi, yaitu jika ke 3 responden menjawab "Sangat Setuju" bernilai 5 maka hasilnya 5x5 = 25 kemudian dikalikan jumlah pertanyaan sebanyak 36 sehingga total maksimal diperoleh sebesar 445. Untuk menghitung keseluruhan sekor sebagai berikut:

$$
\begin{aligned}
& \text { Hasil }=\frac{\text { Skor Diperoleh }}{\text { Skor Maksimal }} \times 100 \% \\
& \text { Hasil }=\frac{388}{445} \times 100 \% \\
& \text { Hasil }=87,19 \%
\end{aligned}
$$


Dari jumlah persentase skor yang diperoleh sebesar 87,19\% dapat disimpulkan menggunakan tabel hasil tersebut berada pada urutan nomor 1 sehingga dapat disimpulkan hasil pengujian usability diperoleh kesimpulan menurut responden yaitu "Sangat Setuju" bahwa pengembangan tersebut telah sesuai.

\section{Pengujian Aspek Fungsionality}

Sejauh mana perangkat lunak mampu menyediakan fungsi yang memenuhi kebutuhan yang dapat digunakan dalam kondisi tertentu, berikut adalah pengujian pengujian Functional Suitability.

Tabel 3. Hasil Pengujian Functionality

\begin{tabular}{|c|c|c|c|c|}
\hline No & Karakteristik & Ya & Tidak & Skor \\
\hline \multicolumn{2}{|c|}{ Testing Masuk } & 1 & $\mathbf{0}$ & \\
\hline 1 & Apakah terdapat error saat membuka halaman masuk? & 2 & 0 & 2 \\
\hline 2 & Apakah sistem dapat menampilkan pesan error? & 0 & 2 & 0 \\
\hline 3 & $\begin{array}{l}\text { Apakah password sudah dapat dibaca oleh sistem dan tidak } \\
\text { menerima form kosong? }\end{array}$ & 2 & 0 & 2 \\
\hline 4 & $\begin{array}{l}\text { Apakah aplikasi dapat mengakses halaman dasboard tanpa } \\
\text { melakukan Login? }\end{array}$ & 2 & 0 & 2 \\
\hline \multicolumn{2}{|c|}{ Testing Dasboard } & Ya & Tidak & Skor \\
\hline 1 & Apakah halaman dasboard berjalan dengan baik? & 2 & 0 & 2 \\
\hline \multicolumn{2}{|c|}{ Testing Halaman Menu } & Ya & Tidak & Skor \\
\hline 1 & Apakah halaman menu paket dan berjalan dengan baik? & 2 & 0 & 2 \\
\hline 2 & $\begin{array}{l}\text { Apakah fitur pencarian, shorting dan paging berjalan } \\
\text { dengan baik? }\end{array}$ & 2 & 0 & 2 \\
\hline \multicolumn{2}{|c|}{ Testing Halaman Tabel Menu } & Ya & Tidak & Skor \\
\hline 1 & Apakah halaman tabel menu berjalan dengan baik? & 2 & 0 & 2 \\
\hline 2 & Apakah sistem dapat menampilkan order masuk? & 2 & 0 & 2 \\
\hline 3 & $\begin{array}{l}\text { Apakah sistem menampilkan kode pembelajaan dapat } \\
\text { mengubah pembayaran? }\end{array}$ & 2 & 0 & 2 \\
\hline \multicolumn{2}{|c|}{ Testing Fungis Tambah Data } & Ya & Tidak & Skor \\
\hline 1 & $\begin{array}{l}\text { Apakah sistem dapat menambahkan data menu } \\
\text { baru dengan baik? }\end{array}$ & 2 & & 2 \\
\hline \multicolumn{2}{|c|}{ Testing Ordering } & Ya & Tidak & Skor \\
\hline 1 & Apakah halaman task ordering berjalan dengan baik? & 2 & 0 & 2 \\
\hline 2 & $\begin{array}{l}\text { Apakah halaman dapat memuat data pemesanan dengan } \\
\text { baik? }\end{array}$ & 2 & 0 & 2 \\
\hline \multicolumn{2}{|r|}{ Testing Fungsi Cetak Tagihan } & Ya & Tidak & Skor \\
\hline 1 & $\begin{array}{l}\text { Apakah sistem menampilkan struk tagihan kemudian dapat } \\
\text { dicetak? }\end{array}$ & $\mathbf{0}$ & 2 & 0 \\
\hline \multicolumn{2}{|c|}{ Testing Keluar Web Penjual } & Ya & Tidak & Skor \\
\hline 1 & Apakah fungsi keluar dapat berjalan dengan baik? & 2 & 0 & 2 \\
\hline \multicolumn{2}{|c|}{ Total Skor } & & & 26 \\
\hline
\end{tabular}


Berdasarkan total skor yang diperoleh masing - masing bagian dan di jumlahkan selanjutnya dapat dihitung dengan konsep skala likert yaitu:

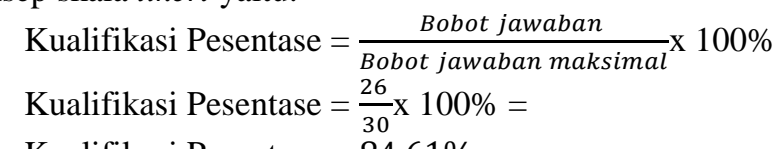

Kualifikasi Pesentase $=84,61 \%$

Berdasarkan hasil pengujian fungsional suitability menghasilkan persentase sebesar 84,61\% dengan hasil tersebut maka dapat disimpulkan berdasarkan kriteria persentase hasil uji terhadap aspek fungsional suitability dapat disimpulkan bahwa responden menilai sistem yang dibangun telah "Sukses".

\section{SIMPULAN}

Dari penelitian ini dapat disimpulkan Perancangan sistem informasi pemasaran dan penjualan dengan menggunakan $w e b$, dirancang menggunakan metode pengembang sistem prototype, dimodelkan menggunakan UML seperi use case, activity dan class Diagram, selanjutnya dilakukan pengkodingan menggunakan sistem berbasis web sehingga dengan mudah diakses, agar tercipta aplikasi yang sesuai tujuan pengembang dengan mengikut sertakan pengguna didalamnya. Mengimplementasikan aplikasi promosi dan pemasaran paket catering, promosi serta penyampaian informasi paket catering dan harga paket secara detail kepada konsumen serta dilengkapi dengan transaksi penjualan paket catering.

\section{REFERENSI/DAFTAR PUSTAKA}

Ahdan, S. and Sari, P. I. (2020) 'PENGEMBANGAN APLIKASI WEB UNTUK SIMULASI SIMPAN PINJAM (STUDI KASUS: LEMBAGA KEUANGAN SYARIAH BMT L-RISMA', Jurnal Tekno Kompak, 14(1), pp. 33-40.

Bunafit, N. (2014) ‘Aplikasi Sistem Pakar dengan PHP dan Editor Dreamweaver', Gava Media.

Irvansyah, F., Muhaqiqin and Setiawansyah (2020) 'Aplikasi pemesanan jasa cukur rambut berbasis android', 1(1), pp. 26-32.

Kurniawan, I., Setiawansyah and Nuralia (2020) 'PEMANFAATAN TEKNOLOGI AUGMENTED REALITY UNTUK PENGENALAN PAHLAWAN INDONESIA DENGAN MARKER', Jurnal Informatika dan Rekayasa Perangkat Lunak, 1(1), pp. 9-16.

Megawaty, D. A. et al. (2020) 'SISTEM MONITORING KEGIATAN AKADEMIK SISWA', 14(2), pp. 98-101.

Mulyanto, A., Nurhuda, Y. A. and Khoirurosid, I. (2017) 'Sistem kendali lampu rumah menggunakan smartphone Android', Jurnal Teknoinfo, 11(2), pp. 48-53.

Pasha, D. and Suryani, E. (2017) 'Pengembangan Model Rantai Pasok Minyak Goreng Untuk Meningkatan Produktivitas Menggunakan Sistem Dinamik pada PT XYZ', JATISI (Jurnal Teknik Informatika dan Sistem Informasi), 3(2), pp. 116-128.

Solichin, A. (2016) Pemrograman web dengan PHP dan MySQL. Penerbit Budi Luhur.

Suryono, R. R., Nurhuda, Y. A. and Ridwan, M. (2019) 'Analisis Perilaku Pengguna Sistem Informasi Pengetahuan Obat Buatan Untuk Kebutuhan Swamedikasi', Jurnal Teknoinfo, 13(1), p. 1. doi: 10.33365/jti.v13i1.134.

Wardana, S. H. (2010) Menjadi Master PHP dengan Framework Codeigniter. Elex Media Komputindo. 